\title{
Verification of Gated Radiation Therapy: Dosimetric Impact of Residual Motion
}

\author{
Inhwan Yeo*, Jae Won Jung ${ }^{\dagger}$ \\ *Loma Linda University Medical Center, Loma Linda, CA, ${ }^{\dagger}$ East Carolina University, NC, USA
}

\begin{abstract}
In gated radiation therapy (gRT), due to residual motion, beam delivery is intended to irradiate not only the true extent of disease, but also neighboring normal tissues. It is desired that the delivery covers the true extent (i.e. clinical target volume or CTV) as a minimum, although target moves under dose delivery. The objectives of our study are to validate if the intended dose is surely delivered to the true target in gRT and to quantitatively understand the trend of dose delivery on it and neighboring normal tissues when gating window (GW), motion amplitude (MA), and CTV size changes. To fulfill the objectives, experimental and computational studies have been designed and performed. A custom-made phantom with rectangle- and pyramid-shaped targets (CTVs) on a moving platform was scanned for four-dimensional imaging. Various GWs were selected and image integration was performed to generate targets (internal target volume or ITV) for planning that included the CTVs and internal margins (IM). The planning was done conventionally for the rectangle target and IMRT optimization was done for the pyramid target. Dose evaluation was then performed on a diode array aligned perpendicularly to the gated beams through measurements and computational modeling of dose delivery under motion. This study has quantitatively demonstrated and analytically interpreted the impact of residual motion including penumbral broadening for both targets, perturbed but secured dose coverage on the CTV, and significant doses delivered in the neighboring normal tissues. Dose volume histogram analyses also demonstrated and interpreted the trend of dose coverage: for ITV, it increased as GW or MA decreased or CTV size increased; for IM, it increased as GW or MA decreased; for the neighboring normal tissue, opposite trend to that of IM was observed. This study has provided a clear understanding on the impact of the residual motion and proved that if breathing is reproducible gRT is secure despite discontinuous delivery and target motion. The procedures and computational model can be used for commissioning, routine quality assurance, and patient-specific validation of gRT. More work needs to be done for patient-specific dose reconstruction on CT images.
\end{abstract}

Key Words: gated radiation therapy, residual motion, dosimetric evaluation

\section{Introduction}

When a clinical target volume (CTV) is located within a moving part of a patient, gated radiation therapy (gRT) is pur-

This study was in part supported by Varian Medical Systems, Inc. The first author is appreciative of Dr. Paul Keall for helpful consultation when he was implementing gated radiation therapy and Ms. Lili An for her help in the area of image transfer for treatment planning.

Received 8 August 2014, Revised 3 September 2014, Accepted 4 September 2014

Correspondence: Inhwan Yeo (medicphys@hotmail.com) Tel: 1-909-558-4904, Fax: 1-909-558-4083

(C) This is an Open-Access article distributed under the terms of the Creative Commons Attribution Non-Commercial License (http://creativecommons.org/icenses/by-nc/3.0) which permits unrestricted non-commercial use, distribution, and reproduction in any medium, provided the original work is properly cited. sued, that employs a finite phase window. The window typically incorporates multiple phases of the moving cycle of breathing, which is thus associated with residual motion. ${ }^{1-3)}$ Multiple CTVs corresponding to the multiple phases within the window form an internal target volume (ITV), when added together. ${ }^{4)}$ This ITV geometrically includes the true CTV and normal tissue components, due to motion and phase changes within the window, which otherwise without motion is encompassed by the CTV only.

A treatment plan is optimized on the ITV and as a result beam delivery is performed to irradiate not only the CTV, but also the normal tissues that were incorporated into the ITV. Then, we believe that the quality assurance procedure for gRT verification can be reduced into (1) testing delivery that is as- 
suring the reproducibility of the determined radiation delivery from planning when the delivery is interrupted due to gating (i.e. time delay) and (2) testing dose deposition that is assuring dose coverage of the CTV within the ITV, while CTV is in motion (i.e. motion).

The first test involves measurement under gated condition, and can thus be straightforwardly performed. The second test is becomes a more clinical problem. As the same gating window set for planning is used for treatment, this test may then be related to assuring breathing reproducibility by comparing a portal image of a patient under setup with a digitally reconstructed radiograph from a treatment planning system (TPS). Such verification is recommended by AAPM TG 76. ${ }^{1)}$

The above two steps in principle are sufficient for gRT validation, and if these are proven acceptable, then the intended dose will certainly be delivered to the target of concern. However, there are practical limitations in visually validating gated RT in terms of image reproducibility, which motivates the quantitative verification of the delivery for quality assurance. Furthermore, we find it interesting as well as clinically necessary to understand in detail the trend of dose delivery on the CTV as well as the neighboring normal tissues, particularly when gating window (GW), motion amplitude (MA) and CTV size change. This becomes even more important, if the breathing is not reproducible between imaging and delivery, which is often possible due to base line shift and breathing pattern changes, ${ }^{12)}$ and thus how the dose was delivered needs to be reconstructed.

Several investigators have studied on the accuracy of gRT. Among them, Kubo and Wang) have carried out the above task (1) and showed good agreement between intermittent- gated deliveries and non-gated continuous delivery of sample intensity-modulated fields based on dynamic multileaf collimator (MLC) operation. They also compared nongated delivery with gated delivery using a relatively small size of $9.4 \%$ as a gating window, and found out a little difference between dose delivered to film with no motion and that to film in motion. This second part of their study belongs to the task (2), although the details of delivery to CTV were not investigated. Hugo et al. ${ }^{3)}$ performed a similar study while using a variable gating window and concluded that the above difference is reduced by reducing the window size. Another study by this group ${ }^{6)}$ demonstrated the change of the planned distribution when delivered to a moving target. This fact was in fact mentioned as dose fuzziness by the prior study of Kubo and Wang. ${ }^{5)}$ This topic was evaluated or demonstrated by other groups. Li et al. ${ }^{7)}$ have shown this through dose profile comparison in the direction of motion employing multiple gating windows. Dietrich et al. ${ }^{8)}$ have evaluated dose distribution in a plane placed perpendicularly to the direction of motion and also three-dimensionally through calculation of dose volume histogram. Nelms et al. ${ }^{9)}$ has demonstrated this on a plane perpendicular to the beam. Unlike the previous two studies by the group of Hugo et al. ${ }^{3,6)}$, Duan et al. ${ }^{10)}$ have investigated the above task (1) on a stationary phantom while gating was triggered by a moving platform. The difference between gated and non-gated delivery was as high as $3.7 \%$ in point dose and 3 $\mathrm{mm}$ in isodose shift.

None of the aforementioned studies has investigated the dose delivery following the specification of the task (2). Therefore, our work primarily aims at explicit dose evaluation on CTV under the impact of residual motion through measurement as well as computational modeling suitably designed and performed in a direction parallel to the direction of motion. Furthermore, our work additionally evaluates dose coverage in neighboring normal tissues to CTV, internal margins (IM), and ITV as GW, MA and CTV size change. This was not clearly investigated in the past.

\section{Materials and Methods}

\section{Experimental method}

Two simplistic targets (CTV) consisting of pyramid (with steps) and rectangular cavities were shown in Fig. 1. The phantom with these cavities was placed on a moving platform (Standard Imaging Inc., Middleton, WI) and scanned on a four-dimensional CT (GE light speed) while the motion was coordinated by the Varian RPM device (Fig. 2). Then the phantom profile in the direction of moving will be pyramid and rectangular shaped, respectively. The scan interval was set at $2.5 \mathrm{~mm}$.

During scanning, the platform traveled over the distance of $4 \mathrm{~cm}$ periodically during the period of 4.5 seconds. Images was acquired and phase-sorted. Gating windows of 30 -to-70\%, 


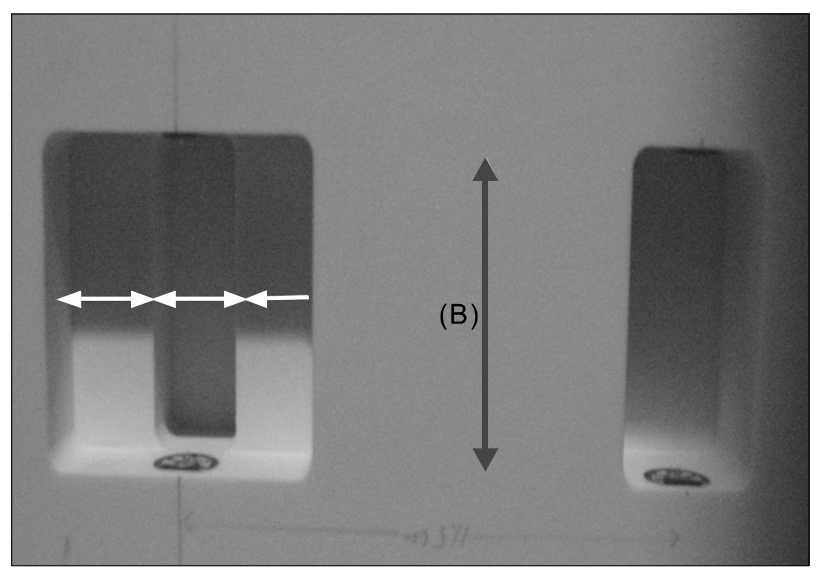

Fig. 1. Flat phantom with pyramid and rectangle-shape cavities. Small metallic balls (in the middle of the blue circles) were placed in the mid distance of each target in the direction of motion. The two targets were hollow volumes drilled within a $5 \mathrm{~cm}$-thick flat phantom. The pyramid shape has two steps (mutually symmetric) in horizontal direction. Each step is $2 \mathrm{~cm}$-wide and $2 \mathrm{~cm}$-deep (width is in horizontal direction indicated by arrows; depth is toward the paper). So, the entire width is $6 \mathrm{~cm}$ and the maximum depth at the center is $4 \mathrm{~cm}$. The rectangular hole is $3 \mathrm{~cm}$ wide horizontally and 3 $\mathrm{cm}$ deep. The vertical dimension for both was $5 \mathrm{~cm}$.

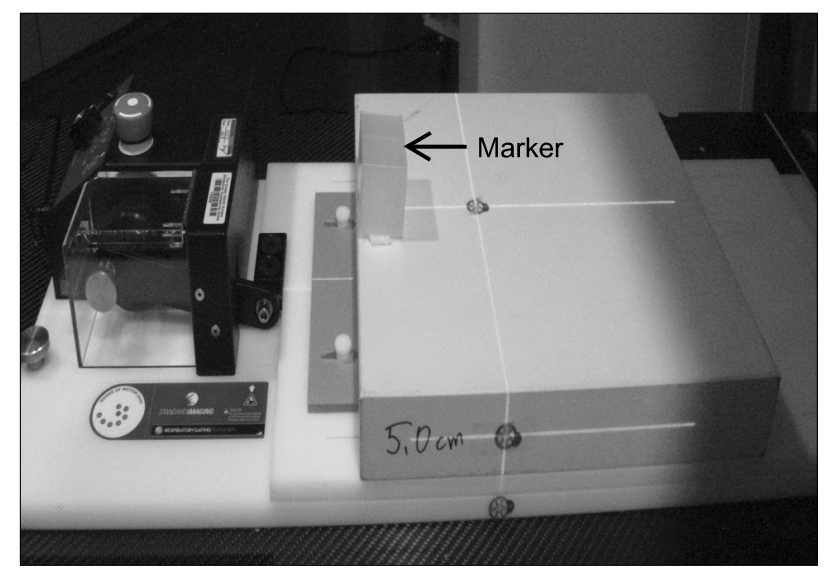

Fig. 2. Flat phantom and a moving platform used for scanning. The reflective marker was laid on the top surface of the phantom which was placed on top of the platform with hollow target cavities facing the platform. Metallic balls were placed outside the phantom at the same imaging slice position of those placed within the pyramid target. The laser was aligned to the balls prior to moving the platform for scanning. The platform is currently at the maximum exhale position or the lowest position in a sinusoidal cycle of breathing and the movement is toward right-hand side.

and 40 -to- $60 \%$ were then selected and images in the two windows were integrated forming target images. Note that $0 \%$

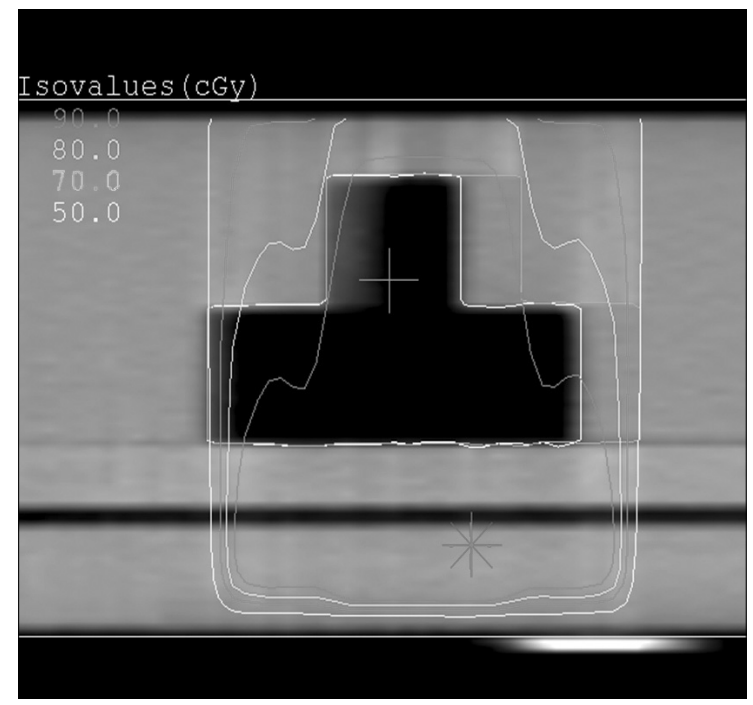

Fig. 3. Isodose distribution designed for the pyramid target for the $40-$ to- $60 \%$ window. The ITV is in orange color and CTV in white. The cross in purple is an isocenter and the star indicates the dose maximum point. The object below the ITV is the scanned image of the platform.

corresponds to the point of maximum inhale and 50\% corresponds to that of maximum exhale. These target images incorporated the CTV and internal margin (IM) due to its motion (i.e. ITV). They were contoured and transferred to a XIO TPS together with scanned images (CMS, Inc., St. Louis, MO, US).

IMRT and conventional beams were designed for the rectangular and pyramid ITVs, respectively, in TPS. Full planning was not attempted, but simplistic beams were designed to achieve the objective of this study. The IMRT beam was prepared by iteratively programming the MLC sequence file of concern and determining MLC position and beamlet weight that generated a pyramid-shape dose distribution where a 50 cGy isodose line covers the lateral limit of the pyramid ITV, in orange color, and a $80 \mathrm{cGy}$ isodose line covers the lateral peak of the higher step of the ITV (see Fig. 3). The beam was posteriorly incident to compose such distribution. The assumption and expectation here is that the CTV (in white color in Fig. 3) should be covered by same shape of the dose distribution when delivered. The IMRT beam thus constructed consisted of multiple successively neighboring beam lets with each opening greater than $1 \mathrm{~cm}$. The conventional beam consisted of a single beam that provided coverage of the rectangular ITV edge 
by a 50 cGy isodose line (the distribution not shown here). The isocenter/weight points for the two beams were placed along the straight line from the center of the bottom surface of each phantom (i.e. CTVs): even though ITVs were greater than the CTVs, the isocenters were placed with respect to the latter. They were placed at the depth of $5.5 \mathrm{~cm}$ from the bottom surface of the platform. The isocenter of the IMRT beam thus placed was at $8 \mathrm{~mm}$ or greater distance away from the edge of the central beam let, unaffected by beam modeling inaccuracy of MLC leaf ends. A dose of 100 cGy was prescribed to each isocenter of the two plans. The goal of planning was to generate desired dose distributions that are suited to this study.

Beams from the planning were transferred to a quality-assurance phantom of a diode array (Mapcheck, SunNuclear, Inc., Melbourne, FL, US) under a $5 \mathrm{~cm}$-thick buildup layer in the TPS. The depth of the new calculation plan on the phantom was $6.3 \mathrm{~cm}$ at which the diodes are positioned. The calculated distribution was transferred to the dose evaluation software associated with Mapcheck (Létourneau et al. ${ }^{11)}$ ). The same beams were also used to irradiate the array under motion with the above two gating windows, travel distance and period (Fig. 4). The array was used with double precision $(5 \mathrm{~mm}$ interval between measurement points), to achieve the objective of this study.

Measured dose profiles were obtained and comparatively evaluated (with vs. without motion) with the objectives of con-

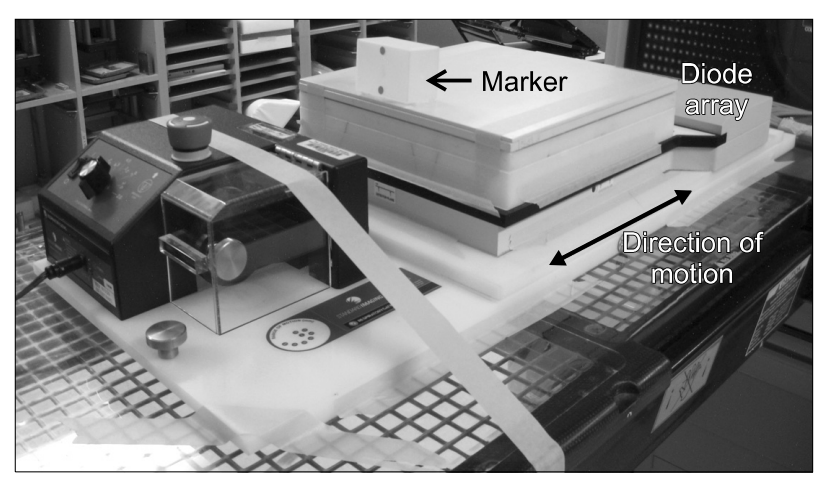

Fig. 4. A diode array placed on a moving platform on a couch under linac. A 5-cm thick water-equivalent phantom was placed on top of the array. Motion coordination stayed the same as that of CT. The phantom, Mapcheck, and the platform were all taped to avoid undesirable positional change during motion. firming the dose delivery to the CTV and investigating dose distributed around the neighboring areas.

\section{Computational method}

In order to understand and evaluate the impact of motion on the delivered dose profile and volumetric dose, computational modeling was carried out. Fig. 5a shows the vertical displacement of marker movement as a function of phase $(\phi)$ or time when the diodes (black dots) are moving in parallel with couch as shown in Fig. 5b. A camera looking at the marker in motion from a front wall sees and captures only the vertical movement of the reflective marker while it moves in parallel with the couch. Graphically in the figure, diodes move following the dashed trajectory lines while such displacement is also coordinated/represented by the vertical displacement of the marker. For example, at the maximum exhale, the diodes are positioned at the positional limit in one direction of the platform (i.e. called base in the figure; Fig. 2 and 4 show the diodes at base position). As they move toward the right-hand side in Fig. 5b, their trajectory captured in the camera moves upward as shown in Fig. 5a. If they fall within a gating window (high-lighted square boxes in the two figures) while in motion, they receive irradiation. The window is sized by the maximum and minimum phases, $\phi_{\min }$ and $\phi_{\max }$, respectively, that limits the associated opening. Note that the diode at the position $\mathrm{A}$ in Fig. 5b, although placed outside the radiation field when it is at base, will fall into the radiation field immediately after it starts to move. On the contrary, the diode at the position B, although placed inside the radiation field when it is at base, will fall outside the radiation field immediately after it starts to move. Some diodes centrally located between these two positional limits will always stay in the window while in motion (i.e. residual motion) and thus continuously receive radiation. As a result, penumbra broadening in the delivered dose profile for diodes positioned placed laterally to the beam (i.e. near points A and B) as well as dose averaging for centrally located diodes, if the beam is modulated, will occur.

The trend of dose profile described above can then be mathematically understood by explicitly expressing dose deposition as a function of phase and position. Assume that $\dot{D}(\underline{x})$ is the 
a

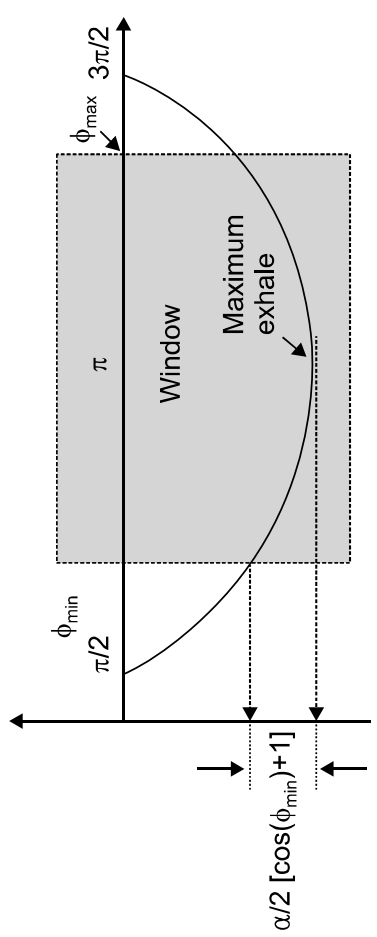

b

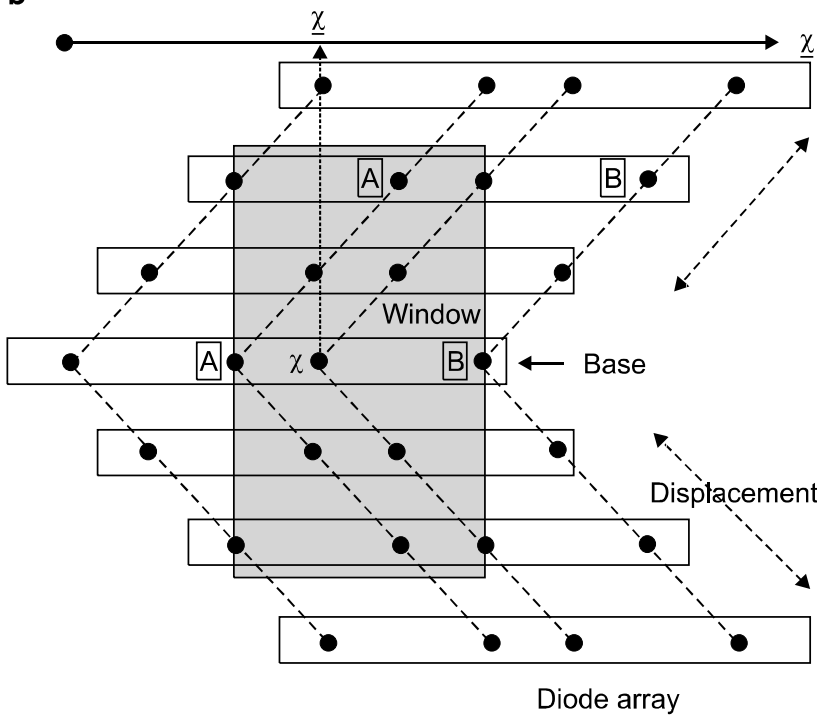

Fig. 5. Position of the diode array under motion corresponding to the position of the reflective marker. (a) Vertical motion of the reflective marker as a function of time or phase. (b) Position change of the array corresponding to the change of the marker position. The base position corresponds to the full exhale phase and the lowest point in the sinusoidal cycle (i.e. $50 \%$ phase). $\phi_{\min }$ and $\phi_{\max }$ are the minimum and maximum phases, respectively, in a selected gating window; $\alpha$ is the amplitude of the breathing cycle directly proportional to the maximum travel distance of the array. $A$ and $B$ are specific positions on the diode array. are the diode positions; $\chi$ is the coordinate of a moving array; $\underline{x}$ is that of a static reference.

dose rate from the beam, measured by diodes, and $\underline{x}$ is the coordinate in a static reference system (i.e. beam is not moving or spatially variable). Under a gated beam, the dose rate at which the beam was delivered can be inversely calculated in eq. (1)

$\dot{D}(\underline{x})=D(\underline{x}) /\left[t\left(\phi_{\max }\right)-t\left(\phi_{\min }\right)\right]$,

from $D(\underline{x})$ which is measured (cumulative) dose over the period of irradiation between $t\left(\phi_{\min }\right)$ and $t\left(\phi_{\max }\right)$. Dose in moving diodes can be calculated by

$D(x)=\int_{t\left(\phi_{\min }\right)}^{t\left(\phi_{\max }\right)} \dot{D}(\underline{x}) d t$,

where the distance $x$ is defined in a moving coordinate system (in the plane of moving diodes). Note that the two dimension variables and the phase and the dimension variables are interrelated by eq. (3).

$x=\underline{x}+c(\alpha / 2)(\cos \phi+1)$, where $\alpha$ is the amplitude of the breathing cycle and $\mathrm{c}$ is a constant scaling the difference between the "vertical" amplitude $\alpha$ and the lateral amount of travel of the diodes $\mathrm{c} \alpha$. The second term in the right-hand side of eq. (3), when $c$ is one, is the vertical travel distance of the marker as a function of $\phi$, as described in Fig. 5a. As c assumes some number, the second term becomes the amount of travel in equation (3). If $\phi$ is replaced by $\phi_{\min }$, it becomes the amount of travel due to residual motion only in a gating window. Therefore, from the dose rate of beam delivery provided by eq. (1), eq. (2) offers deposited dose in moving diodes. Note that $D(\underline{x})$ in eq. (1) can be represented by deposited dose in static diodes. In this study, the above equations were computationally programmed and executed. The profile thus obtained was subsequently compared with the corresponding measured profile under the residual motions employed in this study.

In addition, in order to more rigorously understand the impact of the residual motion, purely computational modeling and demonstration were carried out using the model developed above. This computational study has employed two simplistic breathing patterns that include the sinusoidal pattern used in the experiment as well as a linear pattern ( $\mathrm{V}$-shape; maximum 
exhale at the peak). Actual patterns of patients' breathing may be positioned between these two patterns or represented by a component of the two (George et al. ${ }^{12)}$ ). The rectangular phantom was assumed to have been scanned and ITVs were obtained corresponding to the two gating windows used previously in this study. An idealistic beam shape was considered for the exact coverage of the ITVs and the profiles under the condition of residual motion were obtained.

The computational investigation was further extended to understand the impact more realistically. The change of dose volume of histogram (DVH) for ITV and normal tissues of IM and organs-at-risk (OAR) was acquired as a function of IM, motion amplitude (MA), and CTV size. A terminology of normal tissue was previously used for IM, but for this computational study IM and OAR are separately mentioned. The selected data included the gating window $(\mathrm{GW})$ of 30 -to-70\%, 40-to-60\%, and $50 \%$ for IM; 2, 3, and $4 \mathrm{~cm}$ for MAs; 1,3 , and $5 \mathrm{~cm}$ for CTV. The calculated IMs for the three windows were 2, 0.8 , and $0.1 \mathrm{~cm}$, respectively, and for the three MAs, they were $0.4,0.6,0.8 \mathrm{~cm}$, respectively, assuming a sinusoidal motion. An assumption was made that ITV, IM, and OAR are rectangular and the motion was one-dimensional. Similarly to the above computational study, an idealistic beam shape was considered for the exact coverage of the ITVs. A volume

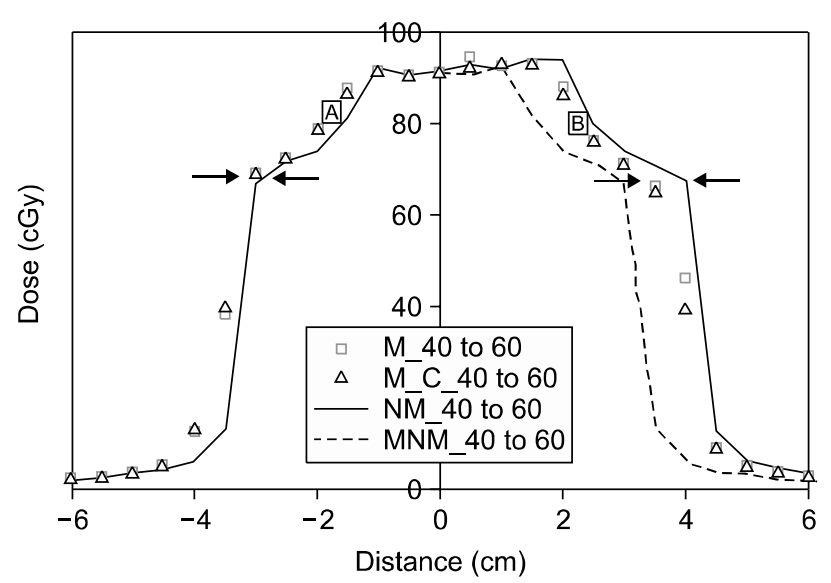

Fig. 6. Dose profiles on a diode array with and without motion under the irradiation of the pyramid beam with the $40-$ to- $60 \%$ window. The distance of zero indicates the position of isocenter. NM corresponds to the measured profile on a static diode array; $\mathrm{M}$ is the measured profile on a moving array; $\mathrm{M}_{-} \mathrm{C}$ represents $\mathrm{M}$ obtained by computer simulation; $\mathrm{MNM}$ is the mirrored profile of NM, displayed on the right hand side only. spanned by $2 \mathrm{~cm}$ placed in the left-hand side of the ITV was assumed to be OAR.

\section{Results and Discussions}

Figure 6 and 7 compare central dose profiles plotted in the direction of motion for the beams described in the method. Among them, NM corresponds to the measured profile on a static diode array under the delivery of the beam transferred from the TPS; the same for M except that the array was moving during the delivery; M_C implies M obtained by computer simulation; MNM is the mirrored profile of NM, displayed on the right hand side only.

Figure 6 shows the profiles of the pyramid beam when delivered within the gating window of 40 -to- $60 \%$. It shows a systematic shift toward the left due to the residual motion associated with the beam gating at 40 to $60 \%$ window (compare NM with $\mathrm{M}$ ). This shift is in fact penumbral broadening explained in the computational method section. Fig. 6 also shows close agreement between the simulated profile (M_C) obtained by using equations (1) through (3) and the measured profile (M). Another fact this study intends to address is whether the CTV is covered by the designed dose distribution. Note that as

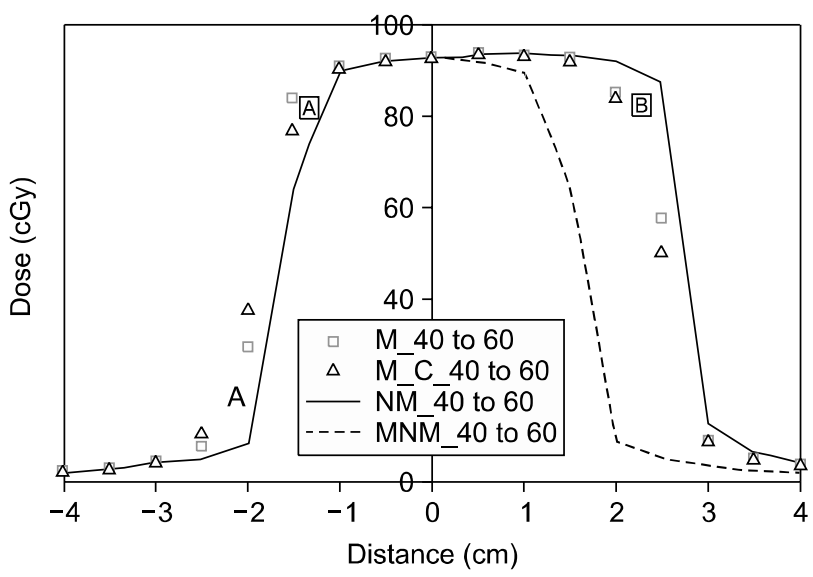

Fig. 7. Dose profiles on a diode array with and without motion under the irradiation of the rectangular beam with the 40-to- $60 \%$ window. The distance of zero indicates the position of isocenter. NM corresponds to the measured profile on a static diode array; $\mathrm{M}$ is the measured profile on a moving array; M_C represents $\mathrm{M}$ obtained by computer simulation; MNM is the mirrored profile of NM, displayed on the right hand side only. 
the beam information was transferred from TPS into the diodes, direct dosimetric coverage of the CTV is not accurately reproducible (Such study may be only possible if the target and dosimeter are identical). However, we can indirectly evaluate the CTV coverage from the profiles in Fig. 6. The coverage of NM was intended to be sufficient for the CTV by planning on the corresponding ITV in TPS. The fact that $M$ is greater than $\mathrm{NM}$ in the left hand side of the profile indicates that sufficient dose coverage of the left half of the CTV was ensured. As the isocenter of the beam is at mid distance of the CTV dimension in the direction of motion, the profile MNM can show the physical extent of the CTV on the other side, wherein the axis of the profile is at where the isocenter is. Then, we can visually identify the greater extent of dose coverage of $\mathrm{M}$ than MNM in the right hand side ensuring sufficient dose coverage for the CTV. Note that the magnitude of MNM is not of interest, but the lateral extent is. The extents of penumbral broadening are somewhat different between the left and right shifts (see the arrows in Fig. 6). This is due to the relative position of the platform (i.e. diodes) under residual motion to the given beam profile (NM). We will further explain this later with simpler and computationally simulated profiles. The slight difference between $\mathrm{M}$ and M_C in the high dose region can be explained by the fact that $\mathrm{M}_{-} \mathrm{C}$ was acquired by numerical execution of eq. (2) using interpolated data points in between the datasets of NM limited in spatial grids. An actual beam characterized by MLCs and other beam features could not be completely represented by such measurement and interpolation. On the contrary, $\mathrm{M}$ represents actual measurements. Another finding is that although not significantly visible, the profile of NM in the high dose area was altered as the diodes received such dose while in motion (M). This is explained by dose smearing due to residual motion. Although not shown here, we have observed that as the window has increased, the amount of penumbral broadening and normal tissue coverage has increased.

Figure 7 shows the profiles of the rectangular beam when delivered within the gating window of 40 -to-60\%. The physics and explanations provided above similarly apply to this figure. However, the above mentioned broadening is more clearly visible in this figure as it is based on the simpler beam profile. In this regard, note that Fig. 7 shows relatively wide and asymmetric penumbral broadening in point $\mathrm{A}$ and $\mathrm{B}$ regions. This can be explained as we understand Fig. 5 more in detail. The point $\mathrm{A}$ is positioned in the region $\mathrm{A}$ and the point $\mathrm{B}$ is in the region $\mathrm{B}$. The diodes in the region $\mathrm{A}$ are outside the beam and those near the point $\mathrm{B}$ are within the beam while in base. At the moment the diodes start to move, while in residual motion the former dwells in the gated window of beam and receives the beam while the latter does not receive the beam. This causes the promotion of signal in the region $\mathrm{A}$ and reduction of signal in the region $\mathrm{B}(\mathrm{M})$ due to residual motion, compared with signals in the base position (NM) under no motion. For inhale gating, the trend will be reversed between the two sides. With this explanation, the broadening in Fig. 6 for the pyramid beam can now be better understood. Fig. 7 also shows the agreement in the magnitude of $\mathrm{M}$ to that of NM in the in-field region, implying time delay due to intermittent delivery is negligible, although this study is not primarily designed for investing such problem.

Another finding from Fig. 7 is that the extent of normal tissue dose coverage is greater in the right hand side (MNM vs. M). This is simply due to the fact that the diodes between the point $\mathrm{B}$ and the CTV are positioned within the beam when they are in or near the base position for the case of exhale gating. Among them, the diodes closer to the CTV initially receives full dose unaffected by penumbral irradiation and, unlike those at the point $\mathrm{B}$, continues to receive in-field dose while in residual motion. This and the simplistic sinusoidal pattern of breathing resulted in the broadening trend.

The validation of a computational model in the experimental study has offered provided Fig. 8 through 11. Fig. 8 shows a simulated profile (NM) that was made to encompass the exact size of the ITV created for the rectangular phantom of $3-\mathrm{cm}$ width. The CTV-to-ITV extension was calculated based on the sinusoidal and $\mathrm{V}$ patterns using the 40 -to-60\% window, and 0.8 and $1.2 \mathrm{~cm}$, respectively, were added to the initial $3 \mathrm{~cm}$. The profile for CTV was made to justly cover the geometrical extent of the CTV. These two profiles, NM and CTV, consist of a highest-dose gradient in penumbral regions, and were assumed to simplify the analysis of this problem. The profile M_s due to the residual motion within the above window shows the decreasing trend of dose as the distances moves away from the CTV. This is due to the penumbral broadening 


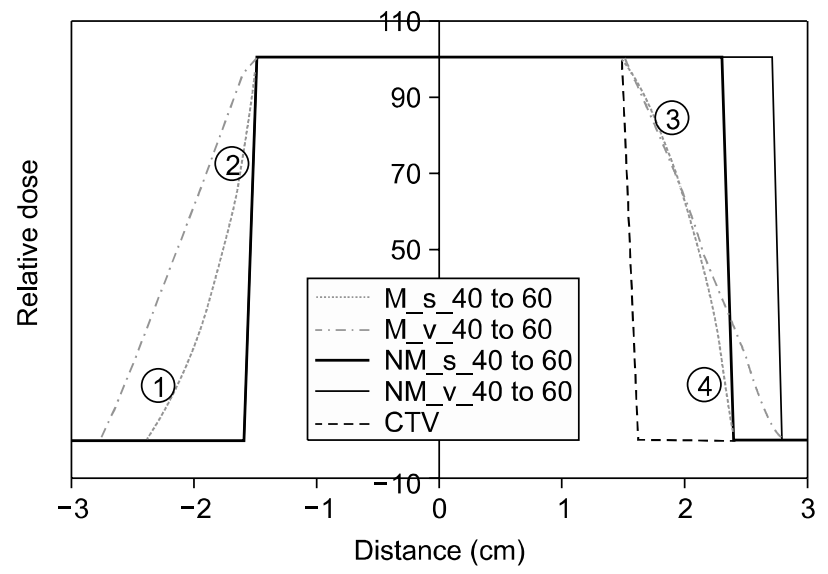

Fig. 8. Simulated dose profiles on a diode array with and without motion under the irradiation of the rectangular beam with the 40-to-60\% window. M_s: the profile under the sinusoidal motion; M_v: the profile under the linear motion; NM_s: the simulated profile without motion for the sinusoidal pattern; NM_v: the simulated profile without motion for the $\mathrm{V}$ pattern; CTV: the profile that justly covers the CTV. Amplitude of motion was $4 \mathrm{~cm}$ and period was 4.5 seconds.

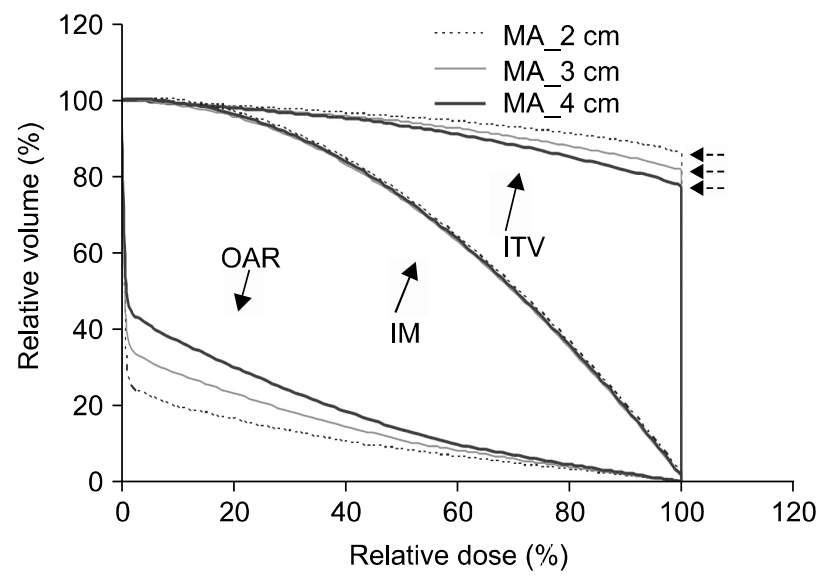

Fig. 9. Dose volume histogram for ITV, IM, and OAR for variable MA.

explained previously for Fig. 7. The trend of profile in internal motion area corresponding to CTV to ITV extension can be explained by the time $(t)$ each dosimeter of concern spends per each step of movement $(d)$ under dose irradiation $(t / d)$. This ratio, $t / d$, is constant independent of position $(x)$ for $\mathrm{V}$-shape movement. However, for sinusoidal movement shown in Fig. 5 it is variable and in fact it increases as the array approaches to the maximum exhale and keeps on increasing until it reaches the maximum exhale. This affects the response of

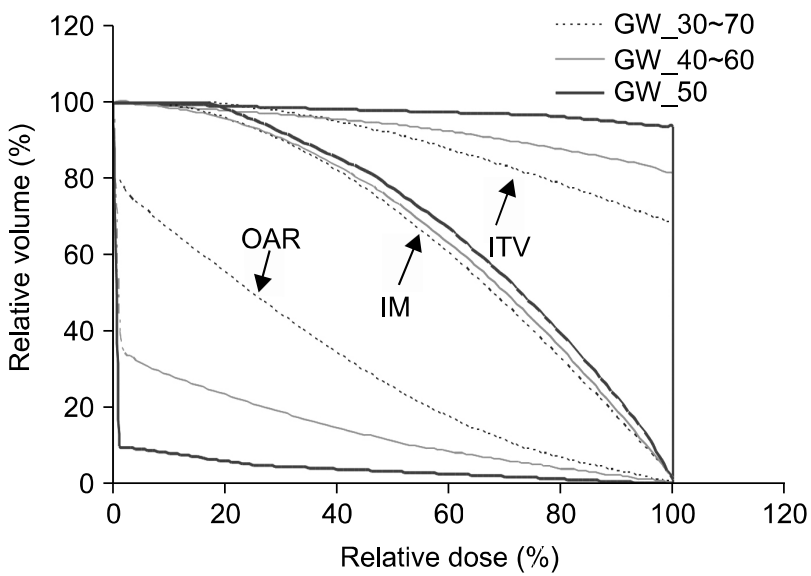

Fig. 10. Dose volume histogram for ITV, IM, and OAR for variable GWs.

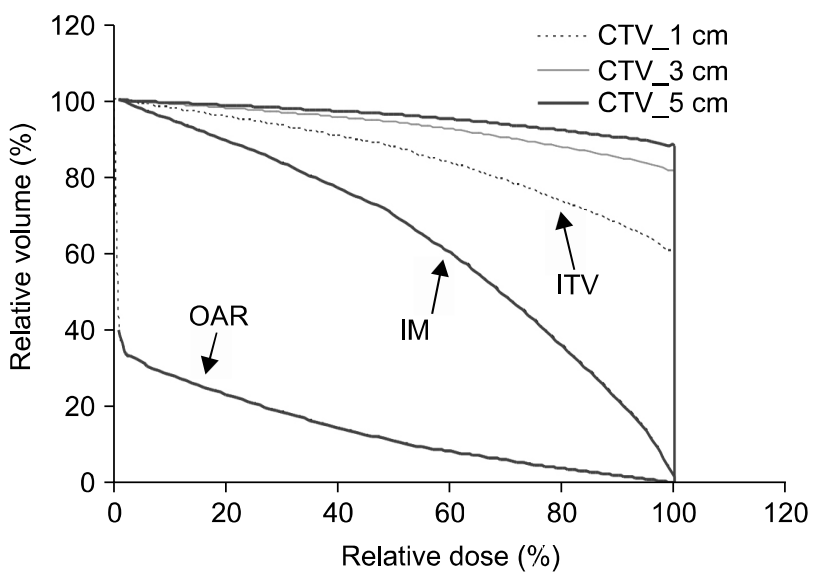

Fig. 11. Dose volume histogram for ITV, IM, and OAR for variable CTV sizes.

each dosimeter as a function of position. At base position, the dosimeters of concern in positions 1 or 3 (group I) shown in Fig. 8 is positioned more distant from the border of beam irradiation than those in positions 2 or 4 (group II; this is referred to as A or B, respectively in Fig. 5 and 7) is. In the vicinity of the beam penumbra and maximum exhale, Group II is associated with greater $t / d$ acceleration (increase/distance) than group I is. So, they dwell longer per time under the penumbral irradiation characterized by sharp increase and decrease of dose. Therefore, for a given travel distance, the dose change in the profile for position 2 and that for position 4 are more rapid than those for the other positions. As dosimeters move their positions from Group II to Group I, $t / d$ decelerates, so the 
rate of dose change gradually reduces. The difference between M_s and M_v came from the fact that the displacement due to the sinusoidal-shape motion is not linearly related to phase or time, while the latter is. Fig. 7 also demonstrates that in spite of residual motion the CTV always receives the prescribed dose when irradiated by a flat dose profile. Computationally, although not shown here, it was also demonstrated that similar profiles and findings exist for the 30-to-70\% window with greater CTV-to-ITV extension.

Figure 9 through 11 show analyses based on dose volume histogram. Note that when a rectangular phantom is assumed, dose line histogram becomes equal to dose volume histogram where the line implies the horizontal axis of a dose profile such as the one in Fig. 8. Fig. 9 shows that the DVHs for ITV and IM decreased as MA increased while GW and CTV size were fixed at $40-$ to- $60 \%$ and $3 \mathrm{~cm}$, respectively. This is due to the increased fractional volume of IM in ITV as MA was increased, while the energy deposition stayed the same. The three points (i.e. dashed arrows) for ITV corresponding to a sharp DVH drop is characterized by a fractional CTV volume that receives full dose which obviously is reduced as MA increased. The volume of OAR did not vary as MA varied (not assumed to vary). So, the amount of volume that receives radiation increased as MA increased. Fig. 10 shows similar findings because the increase of GW while both MA and CTV size was fixed at $3 \mathrm{~cm}$ has the similar impact to that of MA. Fig. 11 shows similar findings for ITV as the increase of CTV size while MA and GW were fixed at $3 \mathrm{~cm}$ and 40-to-60\%, respectively, has a similar impact to that of MA or GW change. The increase of CTV size decreased the fractional volume of IM, so the DVH accordingly increased. The volumes of IM as well as OAR did not change, so their DVHs were unaffected.

Actual patients breathing pattern can be different from the simple patterns used in this study (George et al. ${ }^{12)}$ ), and therefore so is the impact of residual motion. No matter how different it actually is, however, this difference can be understood by rigorously understanding a fundamental physical fact and principle behind such impact. This objective was achieved by employing the simplified motions tried in this study. Experiments and computational results have demonstrated the validity and usefulness of the computational model which can then be used to reconstruct dose actual patients have received once their breathing patterns are known and a programmable motion platform is used. Although the current model alone is limited to dose reconstruction on a plane in beams-eye-view, it will still be useful to investigate potential differences between planning and delivery due to breathing pattern changes. This is important in light of the fact that confirmation of organ reproducibility through portal imaging as recommended by the AAPM TG76 report ${ }^{1)}$ does not guarantee it throughout an entire delivery period. ${ }^{12)}$ Without an actual breathing pattern, the methods and procedures developed in this study can additionally serve for integral, dosimetric quality assurance of every equipment involved in $\mathrm{gRT}$, as recommended by the TG76 report. Namely, they provide a guide on the selection of phantoms (delineating CTV and ITV), imaging, planning, delivery (with and without motion), computational modeling, and evaluation. The evaluation may include conversion of a measured profile without motion using the computational model into a profile with motion and compare it with the corresponding measured profile. This guide can be used for initial commissioning as well as periodic quality assurance. The period and acceptable tolerances should be determined institutionally considering all or part of the following various factors. They include clinical margins used within an institution, robustness of the moving platform that an institution has, imaging thickness, and intrinsic dosimetric accuracy of the dosimeter to be used. In addition, quantitative findings from studies referenced in introduction, initial commissioning results of an institution, and institutional acceptance criteria for IMRT QA (Nelms and Simon ${ }^{13)}$ ) can assist.

\section{Conclusion}

This study through experiments and computations has explicitly investigated and analytically interpreted the impact of residual motion on $\mathrm{CTV}$ and neighboring normal tissues. Clinical target volume received the dose of prescription on ITV, but perturbed by motion averaging effect. Neighboring normal tissues and IM received significant amount of dose due to motion with the decreasing trend of dose profile as the distance moves away from CTV. The dose coverage was affected by changes in gating windows, motion amplitudes, and CTV 
size. Intermittent dose delivery associated with gating was not shown to affect the intended dose coverage on the CTV. The computational modeling developed in this study was validated, and it can be used to quantify dose to CTV as well as neighboring normal tissues. The experimental and computational methods presented in this study can be used for commissioning or routine quality assurance procedure as well as retrospective patient-specific dose validation of gRT by reconstructing delivered dose utilizing respiratory patterns of a patient. Of note for further studies, the current model is limited to static beams and to two-dimensional geometry. More developments need to be done if dynamic beams are intended to be modeled and dose reconstruction is desired to be done on CT images.

\section{References}

1. Keall PJ, Mageras GS, Balter JM, et al: The management of respiratory motion in radiation oncology report of AAPM Task Group 76. Med Phys 3874-900 (2006)

2. Berbeco RI, Nishioka S, Shirato H, Chen GTY, Jiang $\mathrm{SB}$ : Residual motion of lung tumours in gated radiotherapy with external respiratory surrogates. Phys Med Biol 50(16):3655-67 (2005)

3. Hugo GD, Agazaryan N, Solberg TD: An evaluation of gating window size, delivery method, and composite field dosimetry of respiratory-gated IMRT. Med Phys 29(11):2517 (2002)
4. ICRU-62: Prescribing, recording and reporting photon beam therapy (Supplement to ICRU Report 50) (1999)

5. Kubo HD, Wang L: Compatibility of Varian $2100 \mathrm{C}$ gated operations with enhanced dynamic wedge and IMRT dose delivery. Med Phys 27(8):1732 (2000)

6. Hugo GD, Agazaryan N, Solberg TD: The effects of tumor motion on planning and delivery of respiratory-gated IMRT. Med Phys 30(6):1052 (2003)

7. Li XA, Stepaniak C, Gore E: Technical and dosimetric aspects of respiratory gating using a pressure-sensor motion monitoring system. Med Phys 33(1):145 (2006)

8. Dietrich L, Tücking T, Nill S, Oelfke U: Compensation for respiratory motion by gated radiotherapy: an experimental study. Phys Med Biol 50(10):2405-14 (2005)

9. Nelms BE, Ehler E, Bragg H, Tomé W a: Quality assurance device for four-dimensional IMRT or SBRT and respiratory gating using patient-specific intrafraction motion kernels. J Appl Clin Med Phys 8(4):2683 (2007)

10. Duan J, Shen S, Fiveash JB, et al: Dosimetric effect of respiration-gated beam on IMRT delivery. Med Phys 30(8):2241 (2003)

11. Létourneau D, Gulam M, Yan D, Oldham M, Wong JW: Evaluation of a $2 \mathrm{D}$ diode array for IMRT quality assurance. Radiother Oncol 70(2):199-206 (2004)

12. George R, Chung TD, Vedam SS, et al: Audio-visual biofeedback for respiratory-gated radiotherapy: impact of audio instruction and audio-visual biofeedback on respiratory-gated radiotherapy. Int J Radiat Oncol Biol Phys 65(3):924-33 (2006)

13. Nelms BE, Simon JA: A survey on planar IMRT QA analysis. J Appl Clin Med Phys 8(3):2448 (2007) 
Inhwan Yeo and Jae Won Jung : Verification of Gated Radiation Therapy

\title{
여닫이형 방사선 치료의 검증: 잔여 움직임의 선량적 영향
}

\author{
* Loma Linda University Medical Center, Loma Linda, CA, ${ }^{\dagger}$ East Carolina University, NC, USA
}

Inhwan Yeo*, Jae Won Jung ${ }^{\dagger}$

여닫이형 방사선 치료에서, 잔여 움직임으로 인하여 방사선은 실직적인 질병의 부위 뿐만이 아니라 주변 정상조직까지 투여 되도록 되어 있다. 비록 표적이 방사선 투여 중 움직이지만, 방사선이 최소한도로 실질적인 부위 (임상적 표적 체 적)에 조사되기를 원한다. 본 연구의 목적은 여닫이형 치료에 있어서 방사선이 실질적인 표적에 투여되는지를 검증하고, 여닫이 범위, 움직임의 정도 및 임상적 표적체적의 크기의 변화에 따라, 표적및 주변 조직에 투여되는 방사선의 경향을 연구하는 데 있다. 이 목적을 달성하기 위하여, 실험 및 이론적인 연구를 고안하여 수행하였다. 직육각형 및 피라미드형 의 표적 체적을 내포하는 팬텀을 만들어 움직이며 4차원 영상을 얻었다. 여러 여닫이 범위를 얻어진 영상에 적용하여 치료계획용 내부표적(표적체적 및 내부 움직임범위포함)을 만들었다. 직육각형 표적에는 전통적인 치료계획을 그리고 피 라미드형 표적에는 세기 변조형 치료계획을 세웠다. 평판형 다이오드에 치료계획에서 얻어진 여닫이형 방사선을 수직으 로 조사하여 실험적으로 선량평가를 수행하였고 또한 움직이는 상황에서 선량투여를 전산적으로 모사하였다. 본 연구는 두 표적에 대한 반음영 영역의 확장 및 움직임으로 인하여 방해 받았으나 확실하게 수행된 표적 선량투여 그리고 주변 조직에 투여된 상당량의 선량등을 수반하는 잔여움직임의 영향을 정량적으로 그리고 해석적으로 분석하였다. 선량-체 적 히스토그램 분석에 따르면, 내부표적에는 여닫이 범위 또는 움직임 정도가 감소함에 따라 또한 표적체적이 증가함에 따라 선량이 증가함을 보였고, 내부 움직임 범위에 해당하는 체적에 대하여는 여닫이 범위 또는 움직임 정도가 감소함에 따라 선량이 증가하였고, 마지막으로 주변 정상조직에 대하여는, 내부 움직임 범위와는 반대의 경향을 보였다. 본 연구 는 잔여움직임의 영향에 대하여 확실한 이해를 주었고 호흡행태가 재생되는한 불연속적인 투여과 표적의 움직임에도 불 구하고 여당이형 방사선 치료는 안전함을 입증하였다. 본연구에서 수반된 절차와 전산적 모델은 여닫이형 치료의 시작 점 검증, 주기적인 품질관리 및 환자별 검증에 사용될 수 있다. 환자별 영상에 선량을 재구성하는 방향으로 추후 연구가 필요하다.

중심단어: 여닫이형 방사선 치료, 잔여 움직임, 선량검증 